Isabelle Elena TIȚA

Școala doctorală a Facultății de Litere

Universitatea Bucureşti

\title{
DINAMICA SENSURILOR ÎN LIMBAJUL FOTBALISTIC. OBSERVAȚII ȘI EXEMPLE RECENTE
}

Limbajul sportiv, văzut în ansamblul subdomeniilor care îl constituie, se caracterizează prin prezența inovațiilor lingvistice, prin folosirea figurilor de stil, a jocurilor de cuvinte și prin expresivitate colocvială, aspecte pe care nu le regăsim, de exemplu, și în cazul altor limbaje specializate, marcate de referențialitate și caracter denotativ. $\mathrm{Cu}$ atât mai mult, această tendință se reflectă și în domeniul semanticii, la care vom face referire în cele ce urmează.

Prin urmare, ne propunem să discutăm câteva situații particulare care reflectă dinamica limbajului sportiv, cu precădere a limbajul fotbalistic, situații întâlnite recent în presa de specialitate online.

Aceste situații se manifestă fie prin extinderi, fie prin restrângeri de sens, dar și prin deprecieri semantice sau prin înnobilări ale sensurilor. Considerăm presa a fi un instrument util de observare sincronică a acestor fenomene, întrucât reflectă creativitatea și libertatea cu care comentatorii sportivi sau jurnaliștii se raportează la fenomenul sportiv, văzut atât ca modalitate de atragere a publicului "spectator" prin identificarea simpatetică a comentatorului cu publicul în rândul căruia dorește, prin limbaj, să se legitimeze.

Extinderile de sens presupun lărgirea domeniului de referință, ceea ce permite, ulterior, înlăturarea unor restricții contextual-stilistice[1]. Spre exemplu, cuvântul de origine engleză lider, conform DEX 2009, are prima semnificație: „conducător al unui partid, al unei organizații etc.", iar, în al doilea rând, înseamnă „sportiv sau echipă sportivă care se găsește în fruntea unei competiții". Pe lângă sensul deja menționat, se poate vorbi și despre liderul vestiarului.

De asemenea, în cazul cuvântului killer „ucigaş plătit” (vezi MDN s.v.) se observă o lărgire de sens atunci când este folosit în context sportiv, unde înseamnă "o persoană care decide soarta unei activități sportive în ultimul moment, eliminând echipa adversă":

„Dănuț Dumbravă, killerul Timişoarei. Stelistul a marcat 26 de puncte în victoria "militarilor" (31-18) din etapa a 6-a a Superligii." 
Cuvântul decar, care înseamnă „unitate de măsură pentru terenuri, egală cu zece ari" și care, în limbajul fotbalistic, înseamnă ,jucătorul cel mai bun de pe teren, purtătorul tricoului cu numărul zece".

Lărgirea sensului este vizibilă și în cazul cuvântului fan [2] care, în MDN s.v., are sensul de "admirator fanatic al vedetelor ecranului sau ale cântecului" şi care şi-a extins sfera înspre domeniul sportiv, unde se referă la admirația față de o echipă sau față de un jucător profesionist.

Restrângerile de sens sunt mai puțin numeroase și se asociază cu specializarea funcțională, așa încât împrumuturile cu sens uzual pătrund în diverse terminologii. [3]

Spre exemplu, cuvântul event, utilizat în limbajul fotbalistic în sintagma Main event și care înseamnă, după MDN, s.v.: "probă, întrecere, cursă, spectacol sportiv", este folosit în publicistica de specialitate pentru a desemna exclusiv „câștigarea în același an de către aceeași echipă a trei trofee importante": "La Bayern nu este suficient Eventul."

Extinderea semantică rămâne însă cel mai productiv fenomen, un alt exemplu fiind verbul $a$ se bâlbâi, care după MDA 2010 are sensul de "a produce sunete nearticulate sau a articula nedeslușit cuvinte, repetându-le și împiedicându-se în rostirea lor, din cauza unui defect natural, a emoției sau a enervării" și pe care l-am întâlnit într-un comentariu sportiv în direct în sintagma „Niță bâlbâie mingea, dar nu trece de linia porții”. Comentatorul sportiv este familiarizat cu bagajul terminologic al jocului, însă își lasă amprenta, prin folosirea unor cuvinte, sensuri, construcții inedite, cu scopul de a atrage atenția spectatorului și de a oferi un oarecare dinamism discursului. Această extindere semantică poate fi explicată prin specificul comentariului sportiv, construit pe baza unui pattern [4], anglicism prin care se face referire la nucleul terminologic pe care se construiește discursul comentatorului, îmbogățit cu creații lexicale inedite, jocuri de cuvinte, figuri de stil etc., dar și prin analogie, astfel încât comentatorul face o conexiune între incapacitatea portarului de a prinde ferm mingea și incapacitatea de a te exprima clar.

Un alt caz asemănător este cel al verbului a se bărbieri care, potrivit aceluiași MDA înseamnă „a rade barba (cuiva)", înregistrat și cu sensuri secundare precum „a minți, a exagera (cu rea-credință), a înșela, a trage cuiva o bătaie, a păcăli pe cineva cu vorba, a se lăuda". El este utilizat în limbajul sportiv cu o altă semnificație: "a bărbierit foarte multe mingi”. Tendința enunțată anterior este prezentă și în acest caz, unde comentatorul face o analogie între modul în care a fost lovită mingea și procesul de bărbierire, făcând referire, cel mai probabil, la o lovitură tăioasă a mingii 
sau la o lovitură de efect care, deși de-abia a atins mingea, a condus-o cu putere în direcția dorită.

Exemplele citate mai sus subliniază creativitatea acestui sector al limbii, care se îndepărtează de caracterul terminologic al vocabularului sportiv prin inovațiile de limbaj, printr-o retorică a ornării, prin folosirea figurilor de stil și prin expresivitate colocvială, opinie exprimată deja de Rodica Zafiu în Diversitate stilistică în limba română actuală [5].

Așa cum putem observa, în ciuda unui nucleu terminologic care individualizează această disciplină sportivă și care o plasează în interiorul terminologiei sportive, există o relație continuă și productivă între limbajul specializat și limbajul comun, din care se preiau adesea cuvinte cu valoare plastică și metaforică. Mingea este personificată, capătă individualitate proprie, este continuarea piciorului celui care o lovește, iar sportivul nu doar se joacă cu mingea, ci se transformă, metaforic, într-o diversitate de ipostaze dintre cele mai concrete: este un maestru al fineței ridicate la rang de artă profesională (un bărbier haute-couture sau un luptător galactic). În funcție de gradul de apropiere sau de depărtare față de un orizont de așteptare, al publicului și al comentatorului însuși, jucătorul fie se apropie de întruchiparea talentului, fie se coboară la nivelul decepției. Contează foarte mult inclusiv în ce măsură meciul disputat direct în faţa comentatorului și, mediat, în fața sau la urechile publicului are printre echipele protagoniste una preferată, din varii motive, sau ambele echipe sunt la egală distanță de preferința comentatorului. Exemplele amintite anterior fac parte din limbajul cotidian și marchează aceeași tendință de vulgarizare, respectiv de apropiere cât mai mare a limbajului sportiv de publicul spectator. În cazul de față, vulgarizare înseamnă, fără îndoială, subiectivitate debordată pentru a fi împărtăşită, înseamnă identificare, prin cuvinte, atât cu ceea ce se întâmplă pe teren, cât și cu spectatorii/ascultătorii meciului, deveniți parte integrantă a unui spectacol. Astfel, sportul coboară în arena publică, se deschide spre cei care îl urmăresc.

O situație aparte este atunci când transferul de cuvinte se realizează între limbaje specializate, iar această situație poate fi expusă prin următorul exemplu, de această dată întâlnit într-un articol scris, publicat pe un site de specialitate. Astfel, termenul manager, aparținând terminologiei marketingului, are următoarele sensuri în DEX 2009:

„persoană care conduce o entitate economică, îndeplinind, integral sau parțial, funcțiile de previziune și organizare a activității, de coordonare și antrenare a personalului subordonat și de control asupra obiectivelor propuse; „persoană 
care se ocupă cu problemele administrative și organizatorice ale unui sportiv, ale unei echipe sportive ori ale unui colectiv artistic"[6].

Așa cum putem observa, există deja o extindere semantică recunoscută și semnalată ca atare în ultima ediție a Dicționarului Explicativ al Limbii Române, o lucrare lexicografică caracterizată prin accesibilitate față de publicul larg și printr-o atitudine deschisă față de faptele limbii. Așadar, în organigrama cluburilor sportive, cu precădere a cluburilor de fotbal, există această funcție, care se ocupă cu aspectele administrative ale fenomenului sportiv. În $\mathrm{DCR}^{3} \mathrm{nu}$ apare cel de-al doilea sens, cuvântul fiind explicat exclusiv ca: „administrator și coordonator al unei societăți comerciale, al unei reviste etc." și „(eronat) exponent".

$\mathrm{Cu}$ toate acestea, recent am putut observa un fenomen de extindere semantică în interiorul lexicului fotbalistic, unde termenul economic pătrunsese deja. Astfel, am întâlnit următoarele situații:

„Să jucăm cel mai bun fotbal și vedem ce va fi, spune managerul, plin de optimism."

„Liverpool se lansează irezistibil ca și cum managerul său ar fi apăsat un buton invizibil".

Așadar, aceste două ocurențe au fost semnalate în același articol scris, ceea ce sugerează intenția clară a jurnalistului de a folosi acest termen. De asemenea, având în vedere că referințele erau față de antrenorul Jürgen Klopp, arată faptul că sensul actualizat în context nu este același cu cel secundar menționat în dicționar. $\mathrm{Cu}$ toate că vorbim despre un termen împrumutat recent din limba engleză, $\mathrm{DCR}^{3}$ inventariază o multitudine de actualizări contextuale ale acestuia, de pildă: brand manager, store manager, top manager, manager al cotidianului, dar și o bogată familie lexicală: $a$ manageria, managerial, manageriza, managing director, managing partner. Aceste fapte de limbă demonstrează receptivitate, rapiditatea și creativitatea cu care limba noastră reușește să-și însușească un termen străin și să îl transforme într-o resursă foarte productivă din punct de vedere lexical și frazeologic.

De asemenea, dacă în exemplele anterioare (a bâlbâi sau a bărbieri) am ilustrat fenomenul făcând apel la un material lexical autohton, de data aceasta, prin luarea în discuție a lui manager, arătăm cum limbajul sportiv interferează cu o sursă importantă de împrumuturi, limba engleză, care influențează din ce în ce mai mult inclusiv acest sector al lexicului.

Așadar, termenul antrenor, comun sporturilor de masă, termen comun lexicului circulant între subdomeniile care construiesc terminologia sportivă, este concurat de un termen provenit dintr-o altă terminologie, cu 
un sens specializat. Interesant este că în această situație avem de-a face cu o dublă extindere semantică, întrucât acest termen a pătruns în limbajul sportiv denumind persoana care se ocupă cu organizarea clubului și a echipei și a doua oară, cu sensul de antrenor. Având în vedere existența unei unități frazeologice formată de la cuvântul antrenor - și anume antrenor-jucător (conform DCR3: „persoana care are dublă funcție de antrenor și de jucător"), ne putem întreba dacă nu am putea justifica apariția unei noi expresii antrenor-manager, denumind persoana care are atât funcția de a antrena echipa, cât și de a o organiza (ca în exemplele: "Cristiano Bergodi, antrenor - manager la Steaua” sau „De astăzi, echipa are un nou antrenor-manager, nimeni altul decât... Florin Anton, omul care a „dat de podea" cu echipele din futsal din Malta!" [7]). Prin urmare, există o tendință de individualizare a acestui subdomeniu sportiv, care manifestă o predispoziție pentru termenii externi .

Alăturarea acestor doi termeni poate fi explicată prin analogia dintre munca de a organiza o echipă tehnic, dar și socio-economic. Preferința pentru anglicisme este cunoscută în limbajul sportiv, fapt datorat atât modei lingvistice, cât şi economiei de limbaj sau preciziei. De asemenea, poate fi discutată calitatea de termen a unității lexicale manager, având în vedere cele prezentate anterior.

Posibilitatea extinderii semantice în interiorul limbajului fotbalistic poate fi ilustrată cu ajutorul următorului exemplu:

„Când faci hat-trick-ul de schimbări ale lui Budescu la pauză (a fost scos de trei ori în ultimele patru meciuri după prima repriză înseamnă că nu stăpânești o noțiune elementară a fotbalului (...)".

DCR ${ }^{3}$ înregistrează acest termen - hat-trick - cu sensul de „performanță a unui jucător de fotbal sau hochei pe gheață de a înscrie trei goluri consecutive în același meci". În ultimul exemplu, putem observa atât o extindere, cât și o depreciere semantică, fiind clar că în context nu este vorba de o performanță remarcabilă, ci de o presupusă greșeală a antrenorului.

Un alt exemplu este cuvântul englezesc aut, "situație în care un jucător scoate mingea în afara terenului de joc", a cărui ortografie variază, în ciuda faptului că nu mai este resimțit ca un străinism. Recent, am putut observa o extindere semantică, acesta fiind folosit în următorul context: „Jucătorul Anamariei Prodan e OUT de la Dinamo!".

Tendința de lărgire a sensului se observă odată cu apariția expresiei $a$ scoate in aut/afară din joc pe cineva, însă, așa cum putem vedea în exemplul extras, anglicismul este utilizat pentru a transmite faptul că jucătorul este 
dat afară de la clubul sportiv. În exemplul „Florin Gardoş este OUT în acest moment, dar nu e accidentat", acesta are sensul de scos în afara lotului pentru un anumit meci.

În concluzie, dinamica sensurilor în limbajul sportiv reprezintă un aspect important în încercarea de a caracteriza acest tip de limbaj specializat, însă lucrarea de față, date fiind limitele impuse, și-a propus o trecere în revistă a celor mai recente situații în care diferite cuvinte provenind atât din limbajul comun, cât și dintr-un limbaj specializat dobândesc noi sensuri atunci când sunt folosite în limbajul sportiv, cu precădere în cel fotbalistic, pe care l-am analizat folosind articole de presă sportivă online și înregistrări ale meciurilor. Așadar, limbajul sportiv se caracterizează printr-o mișcare proprie, marcată de transferul termenilor dinspre limbajul sportiv spre cel comun și invers.

Așa cum am putut observa, și împrumuturile sunt pretabile extinderii semantice, în ceea ce privește limbajul sportiv remarcându-se capacitatea de adaptare și de utilizare a elementelor de origine străină.

Dinamica sensului subliniază tendința limbajului sportiv de internaționalizare, de creativitate și de receptivitate, ceea ce îl individualizează față de celelalte limbaje specializate, cel dintâi fiind definit și prin ornarea cu diferite expresii metaforice [8], cuvinte cu sens figurat și cu rol expresiv. $\mathrm{Cu}$ toate că restrângerile semantice sunt mai puțin numeroase, un corpus mai bogat ar permite o perspectivă mai generală asupra acestui tip de modificare a sensurilor.

\section{NOTE:}

[1]. Adriana Stoichițoiu-Ichim, Aspecte ale influenței engleze în româna actual, Editura Universității din București, 2006, p. 132.

[2]. În DEX 2009, este definit mai aproape de realitatea actuală: „admirator entuziast, pasionat, al unei vedete, al unei mișcări artistice etc.; simpatizant". Cuvântul este un împrumut cu etimologie dublă (din fr. fan, engl. fan), unde a fost obținut prin scurtarea adj. fanatic: "American English, originally of baseball enthusiasts, probably a shortening of fanatic, but it may be influenced by the fancy, a collective term for followers of a certain hobby or sport (especially boxing); see fancy (n.)" (vezi https://www.etymonline.com/word/fan).

[3]. Adriana Stoichițoiu-Ichim, op.cit., p. 106.

[4]. Simona Constantinescu, Limbajul comentariului sportiv. Pattern și creativitate, Universitatea de Vest din Timișoara, 2016, http://www.diacronia.ro/en/indexing/details/A26648/pdf 
[5]. Rodica Zafiu, Diversitatea stilistică în limba română actuală, Editura Universității din Bucureşti, 2001. http:// ebooks.unibuc.ro/filologie/Zafiu/1.html.

[6]. Sensul secundar devine o componentă a celui principal în $\mathrm{DN}^{3}$ („însoțitor al unei echipe sau al unui campion, care se ocupă cu organizarea, cu conducerea şi cu chestiunile financiare ale turneelor; impresar"), respectiv în MDN 2000, s.v. („cel care conduce o antrepriză, care gerează interesele unui sportiv sau ale unei echipe, care se ocupă cu organizarea și cu chestiunile financiare ale competiţiilor; impresar. 2. exponent").

[7]. http://dambovitapenet.ro/.../4815-young-boys-cu-antrenor-nou-participa-lacupa-boromir, publicat în 16 aprilie 2018.

[8]. Exemple precum Argentina e la terapie intensivă după o umilință istorică ilustrează acest fenomen bine reprezentat în acest tip de limbaj.

\section{REFERINT⿱E BIBLIOGRAFICE:}

Bidu-Vrănceanu, Angela, Lexicul specializat în mișcare. De la dicționare la texte, Editura Universității din București, București, 2007.

Bidu-Vrănceanu, Angela, Lexic științific interdisciplinar, București, Editura Universităţii din București, București, 2001: (http://www.unibuc.ro/eBooks/filologie/lexic).

Bidu-Vrănceanu, Angela (coord.), Lexic comun, lexic specializat, București, Editura Universității din București, București, 2000.

Constantinescu, Simona, Limbajul comentariului sportiv. Pattern și creativitate, Universitatea de Vest din Timișoara, Timişoara, 2016: http:/ / www.diacronia.ro/en/indexing/details/A26648/pdf

Dimitrescu, Florica, Ciolan Alexandru, Lupu Coman, Dicționar de cuvinte recente, ediția a III-a, Editura Logos, București, 2013.

Stoichițoiu-Ichim, Adriana, Vocabularul limbii române actuale: dinamică, influențe, creativitate, București, Editura All, București, 2007.

Stoichițoiu-Ichim, Adriana, Aspecte ale influenței engleze în româna actuală, Editura Universității din București, București, 2006.

Stoichițoiu-Ichim, Adriana, Observații privind influența engleză în limbajul publicistic actual (I), în „Limba română” II, 1996, p. 29-46.

Micul dicționar academic, ediția a III-a, Editura Univers Enciclopedic, București, 2010.

Zafiu, Rodica, Diversitatea stilistică în limba română actuală, Editura Universității din Bucureşti, București, 2001: http://ebooks.unibuc.ro/filologie/Zafiu/1.html.

www.blogsportgsp.ro, accesat la data de 9 mai 2018;

www.gsp.ro, accesat în perioada 25 aprilie - 21 iunie 2018;

www.dexonline.ro, accesat la data de 19 mai 2018;

https://www.etymonline.com/word/fan, accesat la data de 19 mai. 


\title{
Dynamics of Meanings in the Language of Football. Recent Observations and Examples
}

\begin{abstract}
Sporting language, seen from the perspective of all its subsets that make it up, is characterized by the presence of innovations, through figures of speech, wordplay, and colloquial expressions that we don't find, for example, in technical or specialized language, which is marked by objectiveness and references. This tendency is reflected in the field of semantics as well, either through extensions or constraints of meaning, but also through semantic depreciation or meaning ennoblement. We consider the press to be a useful tool in observing these phenomena simultaneously, since they reflect the creativity and degree of freedom with which the sports commentators and journalists refer to the sports phenomena. Subsequently, we will discuss a few particular situations that reflect the dynamics of sports language, with the main focus on football, which were observed recently in the specialized online press. The examples will point out the creativity of this are of language, which distances itself from the specific sport terminology and vocabulary through innovation, despite a terminological nucleus that individualizes each sport, where a continuous productive relationship exists between specialized and common language, from which many words originate.
\end{abstract}

Key words: sporting language, press, figures of speech, creativity, specialized and common language. 